\title{
The Impact of Different Drying Techniques and Controlled Storage on the Development of Advanced Glycation End Products in Skim Milk Powders Using Isotope Dilution ESI-LC-MS/MS
}

\author{
Kataneh Aalaei $^{1}$ • Ingegerd Sjöholm ${ }^{1} \cdot$ Marilyn Rayner $^{1} \cdot$ Eden Tareke $^{2}$
}

Received: 23 January 2017 / Accepted: 30 May 2017 /Published online: 20 June 2017

(C) The Author(s) 2017. This article is an open access publication

\begin{abstract}
The impact of different drying techniques and storage conditions on the formation of carboxymethyl lysine (CML) as an advanced glycation end product (AGE) was investigated in various pilot-scale produced skim milk powders (SMP). CML, an indicator of advanced stages of the Maillard reaction, was analyzed by isotope dilution ESI-LCMS/MS after drying and at intervals during storage for 200 days. The aim of this study is to increase the awareness that the development of AGEs can be hindered by controlled storage, which is mostly neglected at the domestic level by the consumers. Pilot-scale freeze-dryer, spray-dryer, and drumdryer were utilized for manufacturing SMPs. The storage was designed in such a way that it simulated how an average consumer keeps the dried products at home, specifically after opening the packages and how the products may be exposed to unfavorable conditions. To do so, four storage conditions including two temperatures $\left(20^{\circ} \mathrm{C}, 30^{\circ} \mathrm{C}\right)$ and two relative humidities RH $(33 \%, 52 \%)$ were studied and CML formation was monitored using LC-MS/MS. Our results show that the spray-dried samples developed two times higher CML after 200 days, compared to the freeze-dried samples, and this value was 1.6 times for the drum-dried samples. Storage at 52\% RH developed 9.8-10 times more CML in the samples, in comparison with $33 \% \mathrm{RH}$, at the same storage temperature $(P<0.05)$. Our findings demonstrate that AGEs, molecules suspected to be involved in risks factors for auto-immune
\end{abstract}

Kataneh Aalaei

Kataneh.aalaei@food.lth.se

1 Department of Food Technology, Engineering and Nutrition, Lund University, P.O. Box 124, SE-221 00 Lund, Sweden

2 Food for Health Science Centre, Lund University, Medicon Village, SE-223 81 Lund, Sweden diseases, may be formed during storage of SMPs after opening the packages by the consumers.

Keywords Skim milk powder · CML - Storage stability · Maillard reaction $\cdot$ AGE $\cdot$ LC-MS/MS

\section{Introduction}

Skim milk powder (SMP) due to its nutritional profile and wide range of applications in the food industry has become a major ingredient in recent years. According to the Food and Agriculture Organization of the United Nations, world production of skim milk powder showed an increase of $2.8 \%$ in 2016 compared to the previous year and reached 2.3 million tons. The European Union was the largest producer with an annual production of 700,000 t (FAO 2016). For many years, drum-drying was the main technology used for the production of SMP until 1960, when spray-dryers took over due to their energy efficiencies, and nowadays, skim milk powders are almost entirely produced by spray-drying (Pearce and Milk Powder n.d.).

Despite the relatively good storage stability of SMP, the possibility of going through chemical reactions specifically Maillard reactions during processing and shelf-life is not ruled out - a reaction that in the advanced stages leads to the formation of advanced glycation end products (AGEs). Adverse effects of carboxymethyl lysine (CML) and other AGEs on health are currently a controversial issue, and the relation of dietary AGEs to inflammatory and auto-immune diseases such as diabetic complications and renal failure is under indepth discussion (Van Nguyen 2006; Poulsen et al. 2013; Kizer et al. 2014; Bengmark 2007; Liu et al. 2016; Nguyen et al. 2013; Nass et al. 2007). 
AGEs are a heterogeneous and diverse group of molecules which are formed both in food and in body fluids as a result of Maillard reactions. The reaction starts with condensation of a carbonyl compound and an amine group and continues with the formation of an Amadori product. Oxidation of the Amadori product leads to the formation of CML, which is the most frequently used marker of AGEs in food products. CML which can also be formed via oxidation of glucose and formation of glyoxal (GO) is a well-characterized AGE molecule (Hull et al. 2012). Other sources of CML formation include ascorbic acid and polyunsaturated fatty acids (PUFA) (Nguyen et al. 2013). In terms of health, it has been shown that diet-derived CML is associated with circulating CML and contributes to the body's AGE pool (Uribarri et al. 2005; Vlassara and Palace 2002). Binding with AGE receptors, for instance, RAGE, is the AGE's main mechanism to induce their proposed effects in the body (Poulsen et al. 2013). An implication of this issue can be explained by considering the consumers' attitudes and behaviors towards dried products in general. A package of a dried product, for instance, milk powder, will be stored at room temperature after being opened by the consumers and exposed to unfavorable conditions for a significant period of time before its content is fully consumed. This is considered to be safe by the average consumer regardless of what the room temperature and relative humidity is in that place.

Considering the wide application of SMP in the formulation of other food products, and the possibility of mixing with other ingredients and the subsequent thermal processing, AGE content of the SMPs is expected to increase even more. Therefore, there is an urgent need to address this issue. Hence, quantification of CML as one of the significant AGEs in milk products and as a disputed issue has been carried out by either immunochemical or instrumental methods (Hull et al. 2012; Troise et al. 2015; Ahmed et al. 2005; Takeuchi et al. 2015; Drusch et al. 1999; Fenaille et al. 2006; Bosch et al. 2007; Hartkopf et al. 1994; Tareke et al. 2013; Dittrich et al. 2006; Schwarzenbolz et al. 2016; Plaza et al. 2016). A problem, however, is that comparison of the results obtained by the two groups of methods is not possible since the results are reported in different units (kilounits/100 g food and $\mathrm{mg} / \mathrm{kg}$ food). Moreover, accurate data on CML concentration in foods based on a reliable instrumental method such as LC-MS/MS is very limited. Higher sensitivity and accuracy, better reproducibility, and no need for derivatization are the advantages of LC-MS/MS (Poulsen et al. 2013; Tareke et al. 2013; Troise et al. 2015). Although a few studies reporting concentration of CML in food model systems can be found (Lima et al. 2010; Nguyen et al. 2016), the data on CML concentration in real complex food systems especially during storage is scarce.
The early stage of Maillard reactions and its progression in skim milk powders with typical indoor temperature and RH ranges was studied in our previous work (Aalaei et al. 2016a), in which we measured available lysine by a validated dye binding method (Aalaei et al. 2016b).

The aims of the present study were to determine the effects of drying methods in the first stage and secondly to investigate the effects of storage conditions on CML formation in skim milk powders by a sensitive and reliable method using LC-MS/MS, in order to investigate how AGEs are developed in SMPs during long-time storage under a highly controlled environment. The method was employed to evaluate the formation of CML in three types of pilot-scale produced skim milk powders (freeze-dried, spray-dried, and drum-dried) both directly after manufacturing and during 200 days of storage at various storage conditions.

\section{Materials and Methods}

For better understanding, a schematic overview of the conducted experiments in the present study is depicted in Fig. 1.

\section{Materials}

Skim milk ( $0.1 \%$ fat) was obtained from Skånemejerier AB (Malmö, Sweden). $\mathrm{N}^{\varepsilon}$-(1-Carboxymethyl)-L-Lysine (CML) and $\mathrm{N}^{\varepsilon}$-(1-Carboxymethyl)-L-lysine-d4 (d4-CML) were obtained from Larodan Fine Chemicals AB (Malmö, Sweden). Ammonium solution 25\% was obtained from Merck (Darmstadt, Germany). Nonafluoropentanoic acid (NFPA) 97\% was obtained from Sigma-Aldrich (Steinheim, Germany). SPE columns TELOS neo (PCX 200 mg, $6 \mathrm{ml}$ ) were obtained from Sorbent AB (Västra Frölunda, Sweden). All organic solvents were of analytical grade, and all aqueous solutions were prepared in water purified from a Milli-Q reagent water system (Millipore SA, Molsheim, France).

\section{Drying Experiments}

\section{Freeze-Drying}

Freeze-drying was carried out using a pilot-scale freezedryer (Labconco, Missouri, USA). Skim milk ( $0.1 \%$ fat) collected from the process line pre heat treatment (Skånemejerier) was placed into aluminum trays $(1 \mathrm{~cm}$ thickness). The samples were then put into the freezer at $-20{ }^{\circ} \mathrm{C}$ for $24 \mathrm{~h}$ before freeze-drying. The freeze-drying temperature was $-20{ }^{\circ} \mathrm{C}$ in the beginning and reached $20{ }^{\circ} \mathrm{C}$ with a $1{ }^{\circ} \mathrm{C} / \mathrm{h}$ increase rate. The condenser had a temperature of $-50{ }^{\circ} \mathrm{C}$ and the vacuum pressure was 0.02 mbar. The freeze-drying duration was 7 days, and 
Fig. 1 Schematic overview of manufacturing the skim milk powders by three different pilotscale dryers (freeze-dryer, spraydryer, and drum-dryer) and subsequent storage at four storage conditions for 200 days and further analysis of carboxymethyl lysine by LC-MS/MS

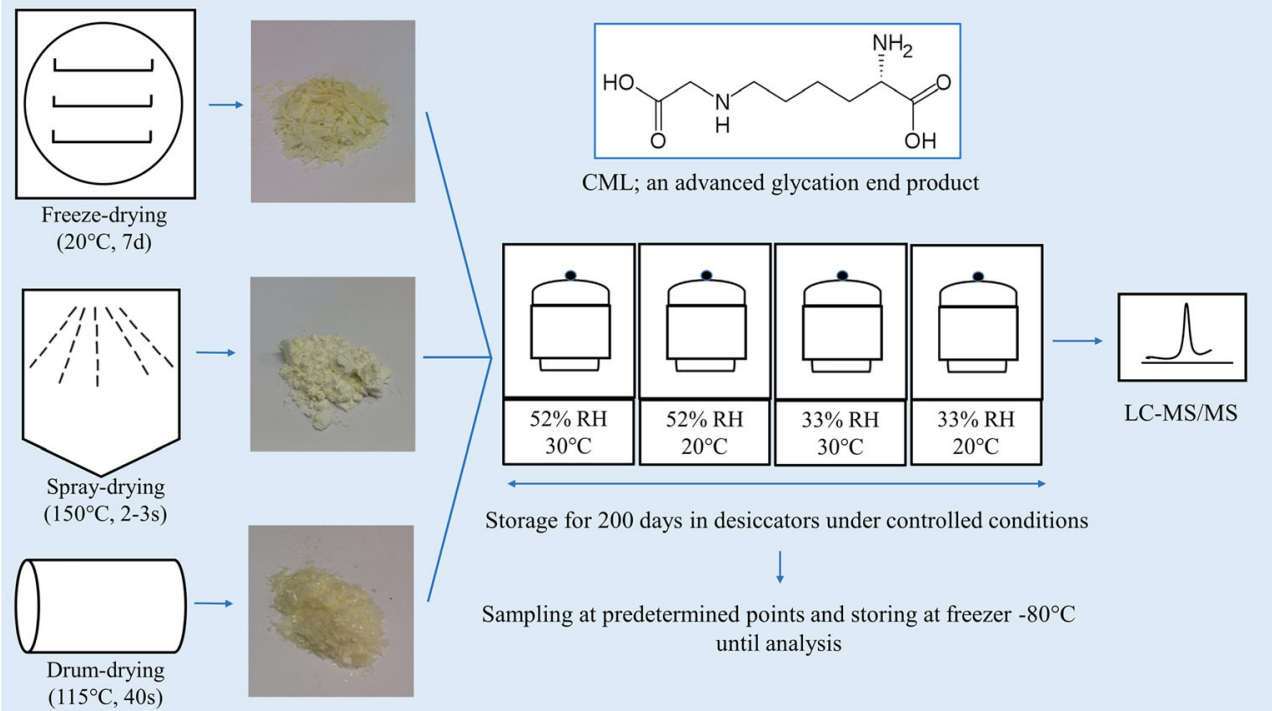

the samples were immediately ground by a mortar and pestle, vacuum-packed in plastic bags, and placed into the freezer at $-20{ }^{\circ} \mathrm{C}$ until further analysis or storage trials.

\section{Drum-Drying}

The process was carried out using a Goudsche Machinefabriek drum-dryer (Waddinxveen, Netherlands). The skim milk ( $0.1 \%$ fat) had been concentrated by dissolving the previously produced freeze-dried SMP in distilled water and had the concentration of $40 \%$ when utilized for drum-drying experiments. Four liters of concentrated skim milk was used for each trial. The surface temperature of the drum was $115^{\circ} \mathrm{C}$ on average, and the residence time was $40 \mathrm{~s}$. The obtained flakes were then ground using a mortar and pestle, vacuum-packed in plastic bags, and placed into the freezer at $-20^{\circ} \mathrm{C}$ until further analysis or storage trials.

\section{Spray-Drying}

A lab-scale Büchi Mini Spray Dryer B-290 (Flawil, Switzerland) was utilized for spray-drying. The inlet temperature of $150{ }^{\circ} \mathrm{C}$ and outlet temperature of $85^{\circ} \mathrm{C}$ were applied. The flow rate of the feed was $0.6 \mathrm{l} / \mathrm{h}$, and the pre-heated air had a flow rate of $540 \mathrm{l} / \mathrm{h}$. The powder was immediately collected, vacuum-packed in plastic bags, and put into the freezer at $-20{ }^{\circ} \mathrm{C}$ until further analysis or storage trials.

\section{Storage of the Samples}

Storage of the samples was carried out in desiccators at two temperatures 20 and $30{ }^{\circ} \mathrm{C}\left( \pm 0.5^{\circ} \mathrm{C}\right)$ and two relative humidities 33 and $52 \%( \pm 3 \%)$. In order to achieve $33 \%$ relative humidity inside the desiccator, $200 \mathrm{~g}$ magnesium chloride was mixed with $25 \mathrm{ml}$ distilled water and stirred until a homogeneous solution was obtained, while $52 \%$ relative humidity was obtained by dissolving $200 \mathrm{~g}$ magnesium nitrate in $30 \mathrm{ml}$ distilled water (Motarjemi 1988). The solutions were placed in the desiccators and allowed to equilibrate for 1 week before adding the samples. The desiccators were then placed in incubators with the desired temperatures.

Glass Petri dishes containing $7 \mathrm{~g}$ milk powder produced by each of the drying methods were placed in the desiccator, which was then placed in an incubator to reach the desired storage temperature. The temperature and relative humidity in the desiccators were monitored once prior to putting the samples in the desiccators, and regularly during storage, with a wireless HygroClip (Mätman 3, Eltex of Sweden). At each pre-determined sampling point, samples were taken out and put in a freezer $\left(-80^{\circ} \mathrm{C}\right)$ until analysis. The analysis was carried out in duplicates.

\section{Determination of CML}

\section{Sample Preparation}

The samples were prepared by hydrolyzing $0.3 \mathrm{~g}$ sample for $24 \mathrm{~h}$ at $110{ }^{\circ} \mathrm{C}$ using $2 \mathrm{ml} 6 \mathrm{M} \mathrm{HCl}$, together with isotope-labeled d4-CML (Larodan Fine Chemicals AB, Malmö Sweden) as internal standard. To protect the samples from oxidation during hydrolysis, the test tubes with samples in $\mathrm{HCl}$ were flushed with nitrogen (bubbling nitrogen gas through the sample) and sealed before incubation. Following hydrolysis, extraction of CML was performed using solid-phase extraction (TELOS neo PCX, Teknolab Sorbent AB, Västra Frölunda, Sweden). The SPE extracts were then evaporated to dryness, reconstituted in $200 \mu \mathrm{l}$ $5 \mathrm{mM}$ NFPA in $\mathrm{H}_{2} \mathrm{O}$, and analyzed using LC-MS/MS (Tareke et al. 2013). 


\section{Quantification of Total CML by LC-MS/MS}

The quantification of CML was performed using highpressure liquid chromatography mass spectrometry (HPLC-MS/MS). Instruments used were Accela UHPLC pump with autoinjector coupled to LTQ Orbitrap Velos Pro mass spectrometer (Thermo Scientific, Waltham, USA). For data quantification and evaluation, Xcalibur ${ }^{\mathrm{TM}}$ 2.2 software (Thermo Scientific) was used. The MS/MS was run in positive electrospray ionization ion trap mode, detecting two selected reaction monitoring (SRM) transitions for CML and two for the internal standard. Solid phase extraction, chromatographic parameters, ion source parameter, and the SRM transitions are the same as described by Tareke et al. 2013 .

\section{Calibration Curve}

The calibration curve was prepared with $0,1,2.5,10,50$, 100 , and $500 \mu \mathrm{g} / \mathrm{ml} \mathrm{CML}$ and fixed amounts $(100 \mu \mathrm{l})$ of IS (d4-CML) with $100 \mu \mathrm{g} / \mathrm{ml}$ concentration. The calibration equation ( $\left.\mathrm{Y}=0.028536 \mathrm{X}, R^{2}=0.9991\right)$ was then used for the calculation of total CML in the samples. Samples containing higher concentrations of CML than the highest concentration in the calibration curve were diluted to ensure the analysis was carried out over the calibrated concentration range.

\section{Scanning Electron Microscopy Analysis}

To prepare samples for imaging with SEM, they were coated by a thin layer of gold-palladium. This step was done to provide a conductive surface on the samples and to decrease the charging problem. To do so, powders were spread on the surface of stubs by using two-sided carbon tapes. Subsequently, the extra powder on the stubs was removed by using a plastic blower. Samples were then put into a SC7640 sputter coater (Laughton, East Sussex, UK). The current was set to $15 \mathrm{~mA}$, and during $3 \mathrm{~min}$, samples were coated with a thin layer of gold-palladium. The thickness of the layer was $10 \mathrm{~nm}$. The samples were subsequently imaged using a Hitachi SU3500 SEM (Tokyo, Japan) with a 5-kV accelerating voltage.

\section{Determination of Water Content During Storage}

Since water plays a critical role in the Maillard reaction, and also due to the importance of the water content in the final calculations, water content of the samples before and at sampling times during storage was quantified. Water content (or the dry matter) of the sample was determined using the standard method of the International Dairy Federation (Rückold et al. 2000). Briefly explaining, samples were dried in an oven (Termaks, Bergen, Norway) at $102^{\circ} \mathrm{C}$ for $2 \mathrm{~h}$. Following this, the samples were kept in a desiccator for $1 \mathrm{~h}$ to reach constant weight before analysis. This analysis was carried out with two replicates.

\section{Determination of Water Activity During Storage}

Water activity of the samples before and at sampling times during storage was measured in duplicate using AquaLab water activity meter Series 3TE (Decagon Devices Inc., Washington, USA). $1 \mathrm{~g}$ of sample was used for each measurement.

\section{Statistical Analysis}

The results in this study are presented as means of two replicates \pm standard deviations. Statistical significance of the data

Table 1 Literature review of CML values in similar products

\begin{tabular}{|c|c|c|c|c|}
\hline Food item & Physical state & CML concentration & Analysis method & Reference \\
\hline Pasteurized milk & Liquid & $16.37 \mathrm{mg} / \mathrm{kg}$ protein & LC-ESI MS/MS & Fenaille et al. 2006 \\
\hline UHT milk & Liquid & $34.1 \mathrm{mg} / \mathrm{kg}$ protein & LC-ESI MS/MS & Fenaille et al. 2006 \\
\hline Powdered infant formula & Powder & $25.67-140.17 \mathrm{mg} / \mathrm{kg}$ protein & LC-ESI MS/MS & Fenaille et al. 2006 \\
\hline Infant foods, stored for 9 months at $37^{\circ} \mathrm{C}$ & Powder & $690-1180 \mathrm{mg} / \mathrm{kg}$ protein & GC-MS & Bosch et al. 2007 \\
\hline $\begin{array}{l}\text { Dairy products } \\
\text { Skim milk }\end{array}$ & $\begin{array}{l}\text { Liquid/powder } \\
\text { Liquid }\end{array}$ & $\begin{array}{l}<\mathrm{LOD}-181,937 \mathrm{mg} / \mathrm{kg} \text { protein } \\
6.04 \mathrm{mg} / \mathrm{kg} \text { protein }\end{array}$ & $\begin{array}{l}\text { LC-MS/MS } \\
\text { LC-MS/MS }\end{array}$ & $\begin{array}{l}\text { Hull et al. } 2012 \\
\text { Hull et al. } 2012\end{array}$ \\
\hline $\begin{array}{l}\text { Infant formulas } \\
\text { UHT milk }\end{array}$ & $\begin{array}{l}\text { Powder } \\
\text { Liquid }\end{array}$ & $\begin{array}{l}82.2-148.1 \mathrm{mg} / \mathrm{kg} \text { protein } \\
184.1 \mathrm{mg} / \mathrm{kg} \text { protein }\end{array}$ & $\begin{array}{l}\text { LC-MS/MS } \\
\text { LC-MS/MS }\end{array}$ & $\begin{array}{l}\text { Troise et al. } 2015 \\
\text { Troise et al. } 2015\end{array}$ \\
\hline $\begin{array}{l}\text { Milk powder } \\
\text { Milk }\end{array}$ & $\begin{array}{l}\text { Powder } \\
\text { Liquid }\end{array}$ & $\begin{array}{l}71 \mathrm{mg} / \mathrm{kg} \text { protein } \\
343 \mathrm{mg} / \mathrm{kg} \text { protein }\end{array}$ & HPLC & Drusch et al. 1999 \\
\hline
\end{tabular}

CML data available in the literature are either reported in KU (kilounits) measured by ELISA (enzyme-linked immunosorbent assay) or milligrams per sample weight and protein weight quantified with instrumental methods (LC or GC). These two groups of values cannot be converted to each other; thereby, only the values measured by instrumental methods are considered in this table 
Fig. 2 Changes of total CML in freeze-dried, spray-dried, and drum-dried SMP during storage at $52 \% \mathrm{RH}, 30{ }^{\circ} \mathrm{C}$. Data points are the average of two replicates, and the error bars represent standard deviations

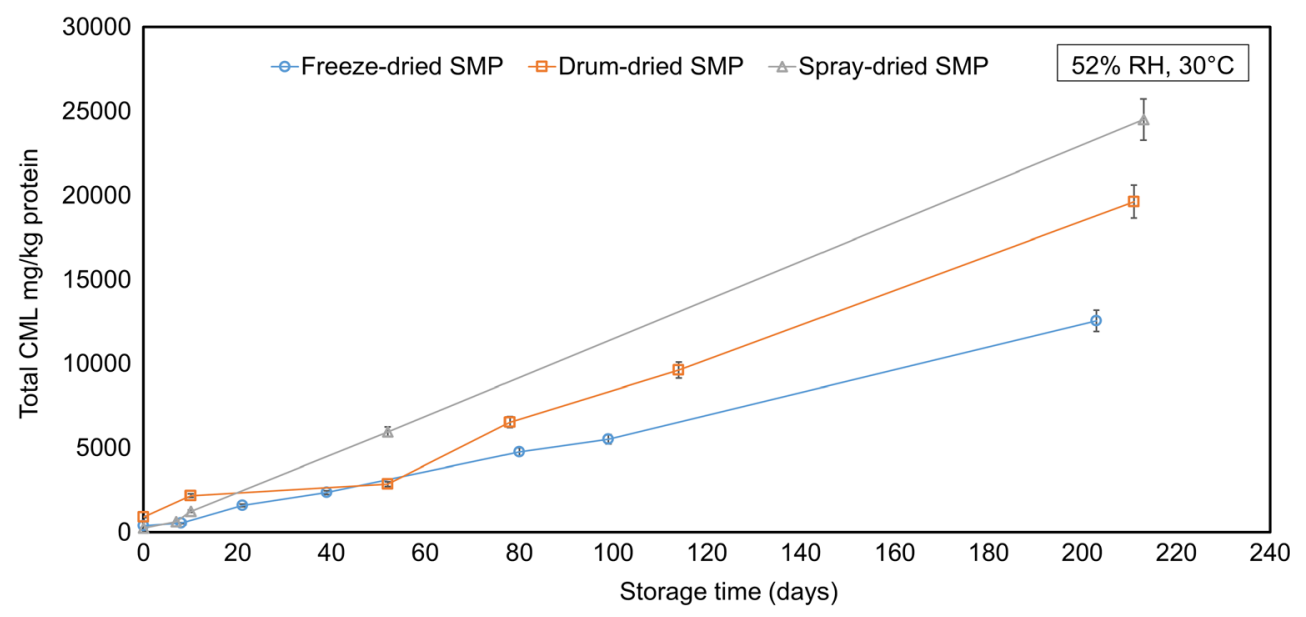

was carried out by Student's $t$ test (two samples assuming unequal variances) at the $95 \%$ significance level using Microsoft Excel 2013.

\section{Results and Discussion}

This section presents and discusses the results of the formation and development of CML in the skim milk powders during the storage at different conditions. The storage environment used in this study was created in the way that it resembled how consumers store an opened package at home.

\section{Initial CML}

Before starting the storage setup and analysis of CML, a nonheat-treated skim milk, collected immediately after fat separation step in a local dairy factory (Skånemejerier), was freezedried and assigned to be the reference sample. The CML concentration in the reference sample was $228.81 \pm 11.44 \mathrm{mg} / \mathrm{kg}$ protein, and our results for skim milk powders before the storage $(t=0)$ are within the reported range of previous studies on milk and milk powder (Fenaille et al. 2006; Bosch et al. 2007; Hull et al. 2012; Troise et al. 2015; Drusch et al. 1999) (Table 1).

\section{The Effect of Storage on Formation of CML}

\section{Storage at $52 \% \mathrm{RH}$ and $30^{\circ} \mathrm{C}$}

Figure 2 shows that development of CML in the spray-dried samples during storage at $52 \% \mathrm{RH}, 30^{\circ} \mathrm{C}$, is significantly higher than the drum-dried and the freeze-dried skim milk powders under the same storage condition $(P<0.05)$. As can be seen, CML values are calculated in milligrams per kilogram of protein. The skim milk powder contained $36 \%$ protein, which means that the values can be easily converted to milligrams per kilogram of sample. Considering the mechanism of freeze-drying, which is drying of the frozen material under vacuum and room temperature, the results of this study agree well with expectations with respect to the freeze-dried sample. The spray-dried skim milk powder contained the
Fig. 3 Changes of total CML in freeze-dried, spray-dried, and drum-dried SMP during storage at $52 \% \mathrm{RH}, 20^{\circ} \mathrm{C}$. Data points are average of two replicates, and the error bars represent standard deviations

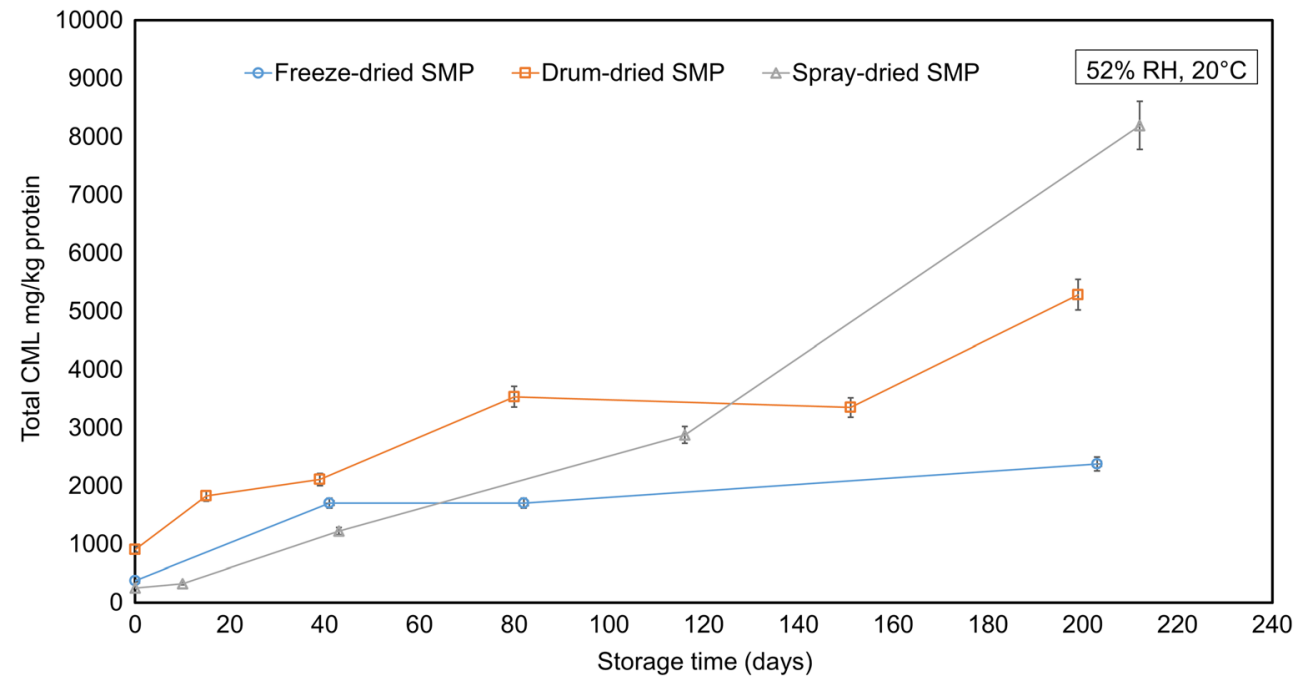


Fig. 4 Changes of total CML in freeze-dried, spray-dried, and drum-dried SMP during storage at $33 \% \mathrm{RH}, 30^{\circ} \mathrm{C}$. Data points are the average of two replicates, and the error bars represent standard deviations

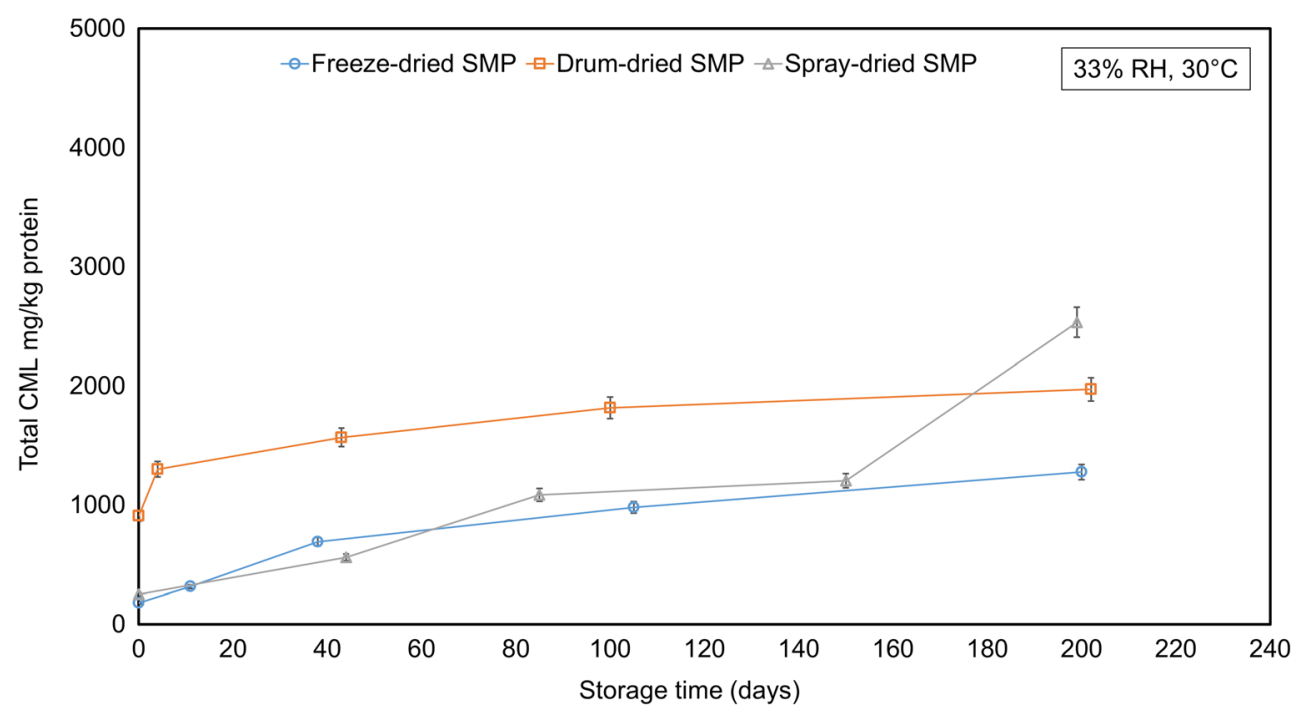

highest amount of CML during and after 200 days of storage at the same storage conditions. Specifically, the CML content in the spray-dried sample at this condition is two times higher than the freeze-dried sample after 200 days of storage. The corresponding value for the drum-dried sample is 1.6 times higher after 200 days, compared to the freeze-dried sample. This clearly highlights the significant impact of the drying technology on the formation of CML and AGEs in SMP $(P<0.05)$.

\section{Storage at $52 \% \mathrm{RH}, 20^{\circ} \mathrm{C}$}

Figure 3 illustrates that when the skim milk powders were stored at $52 \% \mathrm{RH}$ and $20{ }^{\circ} \mathrm{C}$, the gradual formation of CML decreased significantly compared to storage at $52 \%$ $\mathrm{RH}$ and $30{ }^{\circ} \mathrm{C}(P<0.05)$. It should be noted that the scale is different here, pointing out that $\mathrm{CML}$ concentration at $52 \% \mathrm{RH}$ and $20{ }^{\circ} \mathrm{C}$ increased only to approximately
$8000 \mathrm{mg}$ per kg protein in the case of the spray-dried sample. The corresponding value in the previous storage condition (Fig. 2) was around $25,000 \mathrm{mg} / \mathrm{kg}$ protein. With this explanation, we want to emphasize that the effect of storage temperature on CML content was significant $(P<0.05)$. Somewhat surprisingly, the spray-dried samples contain higher concentrations of CML after 200 days of storage, followed by the drum-dried and freeze-dried samples, which is similar to the results for storage conditions of $52 \% \mathrm{RH}$ and $30{ }^{\circ} \mathrm{C}$ (Fig. 2). This, however, occurs after approximately 4 months of storage at this condition. Before that, the drum-dried sample has higher CML compared to the spray-dried sample (Fig. 3).

Our results suggest that the effect of the storage temperature on the development of CML and progression of Maillard reactions in the advanced level is highly significant $(P<0.05)$. By looking back at the previous storage condition $(52 \% \mathrm{RH}$ and $30^{\circ} \mathrm{C}$ ), we realize that the formation of $\mathrm{CML}$ in the
Fig. 5 Effect of drying method and storage conditions on the development of CML before and after 200 days of storage. Data points are average of two replicates, and the error bars represent standard deviations

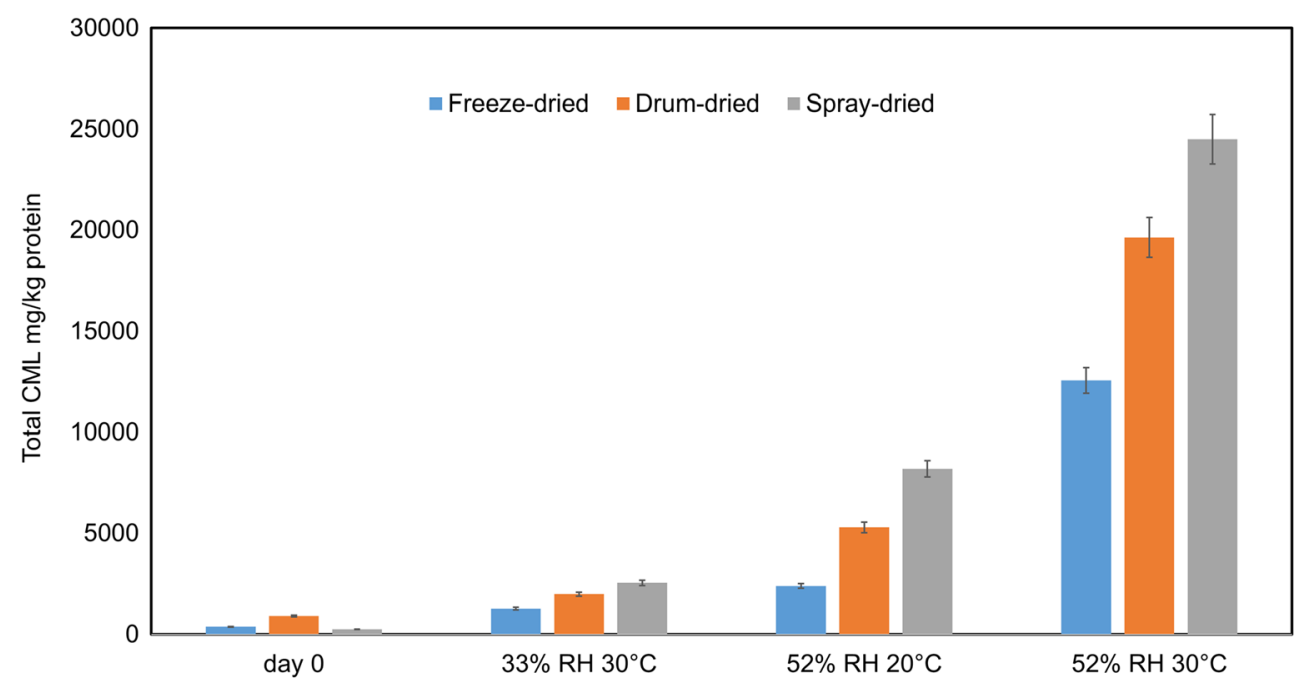




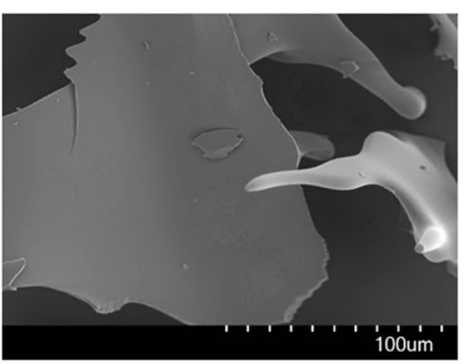

Freeze-dried SMP

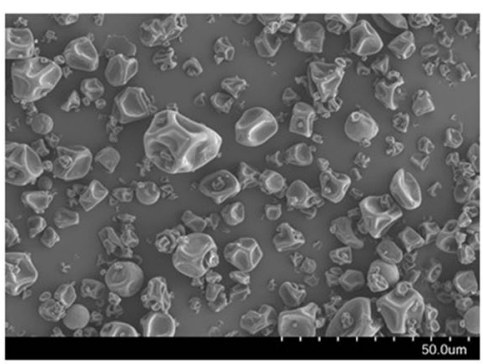

Spray-dried SMP

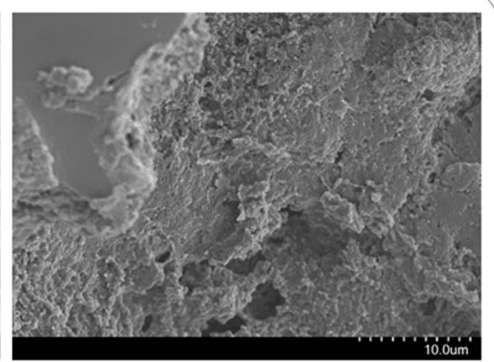

Drum-dried SMP

Fig. 6 Scanning electron microscopy micrographs of skim milk powders before storage (time 0)

freeze-dried, spray-dried, and drum-dried samples after 200 days was $5.3,3$, and 3.7 times higher than storage at $20^{\circ} \mathrm{C}$, respectively.

\section{Storage at $33 \% \mathrm{RH}, 30^{\circ} \mathrm{C}$}

Figure 4 shows that storage at $33 \% \mathrm{RH}$ and $30{ }^{\circ} \mathrm{C}$ led to less CML development than the two previous conditions with $52 \%$ RH. Further, it can be seen that the drum-dried skim milk powder has higher CML compared to the spray-dried and freeze-dried samples at $33 \% \mathrm{RH}$ and $30{ }^{\circ} \mathrm{C}$ storage condition. For the spray-dried sample, CML formation does not increase significantly before 180 days of storage $(P>0.05)$.

To understand the relative humidity effect, CML values at $52 \% \mathrm{RH}$ were compared with the corresponding values at $33 \% \mathrm{RH}$ (at the same storage temperature) and the comparison showed that the skim milk powders stored in the former condition contained 9.8-10 times higher CML after 200 days.

\section{Storage at $33 \% \mathrm{RH}, 20^{\circ} \mathrm{C}$}

Storage at $33 \% \mathrm{RH}$ and $20{ }^{\circ} \mathrm{C}$ did not cause any significant change in the level of CML in any of the samples $(P>0.05)$, and therefore, data is not shown.

\section{Overview of CML Formation During Storage}

It should be emphasized that the storage variables selected in this study are realistic representatives of the climate conditions in many areas. In fact, the temperature and relative humidity in some regions may be even higher than the selected ones in this study. We want to highlight here that the aim of this study was to understand how CML is developed in the products when consumers store an opened package at room temperature and consume the product intermittently over a long time. Nguyen et al. studied the relation between the indoor and outdoor temperatures and relative humidity. They showed that the indoor relative humidity can change between 30 and $70 \%$ during a year (Nguyen et al. 2014).
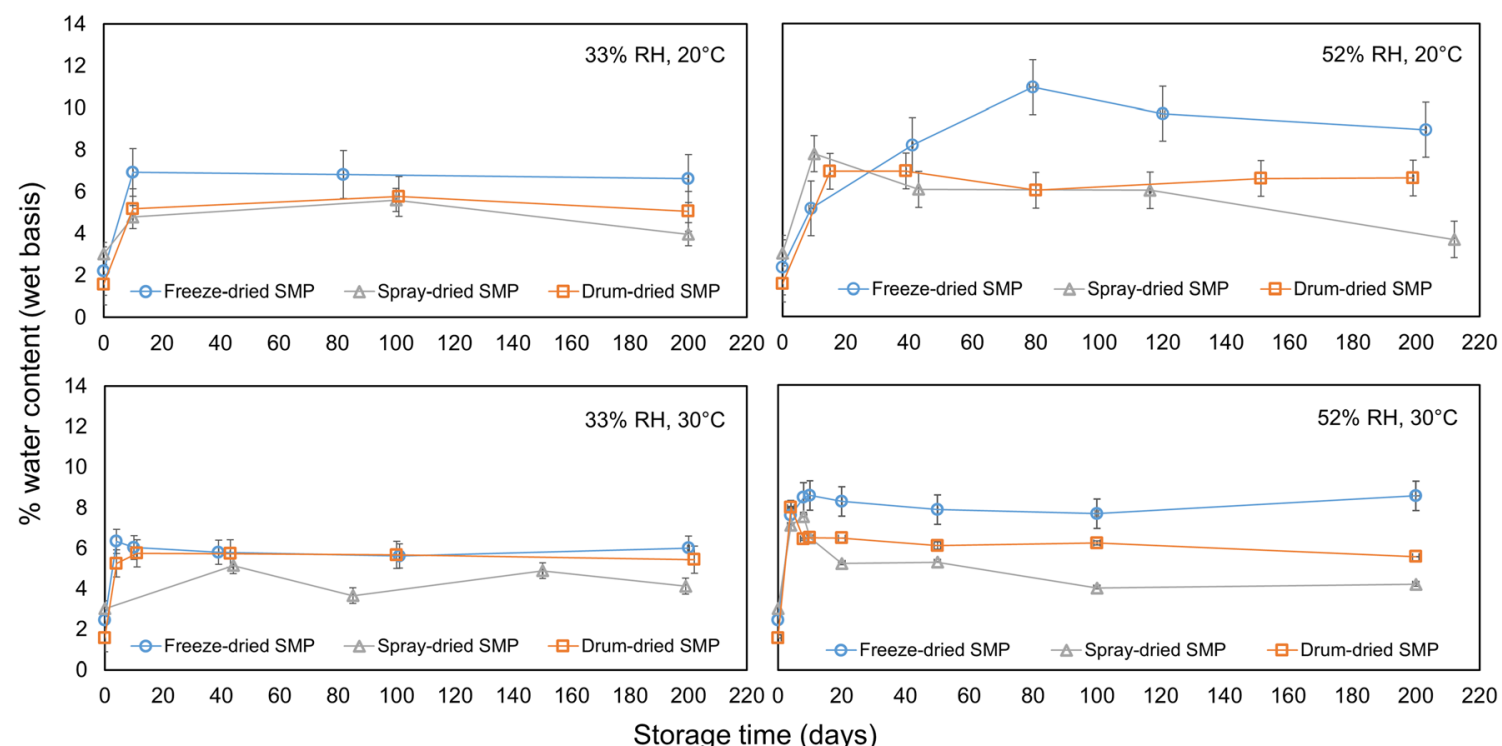

Fig. 7 Changes of water content during storage of skim milk powders. Data points are the average of two replicates, and the error bars represent standard deviations 


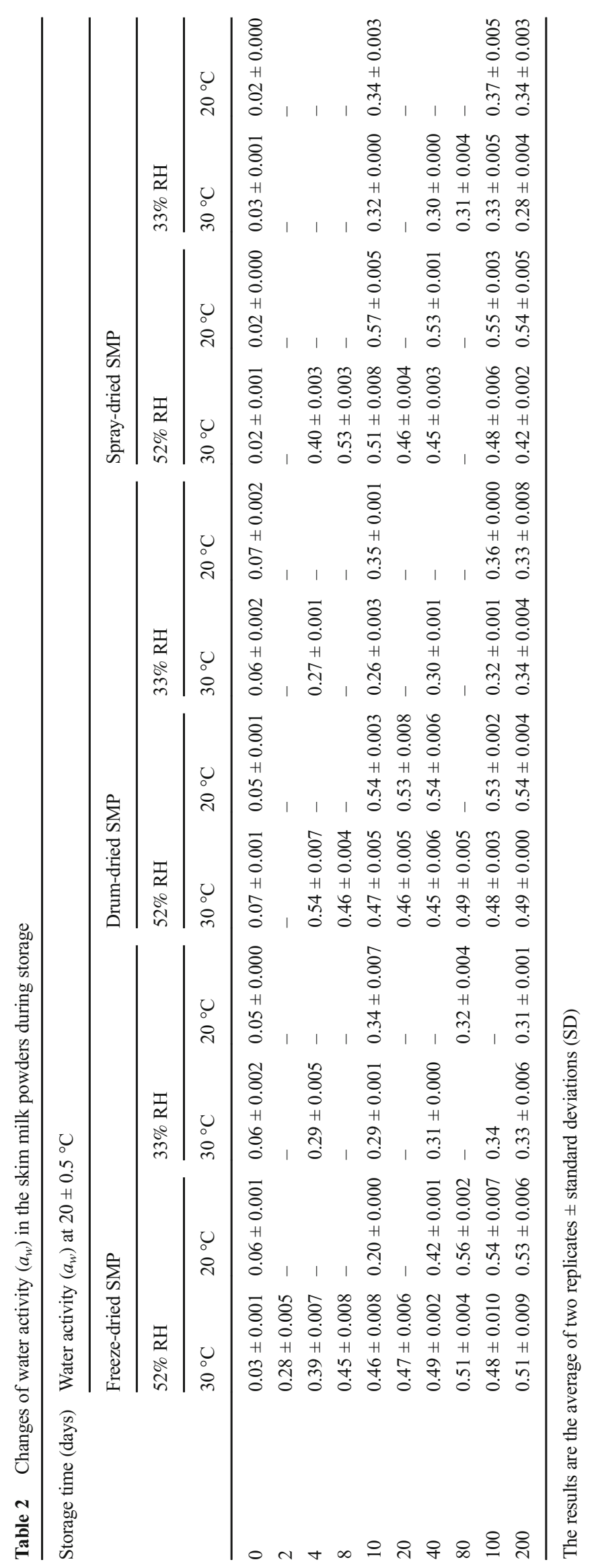


Figure 5 illustrates the significant role of the drying method both on the formation and on the development of CML as an important AGE molecule. The figure clearly indicates that the choice of drying method as well as conditions of storage are major factors in the gradual formation of CML. As can be seen in this figure, before storage $(t=0)$, the drum-dried SMP contains higher CML content compared to the other two types of SMPs, likely longer processing time at this temperature.

In summary, we observed that the spray-dried skim milk powders contained higher levels of CML after 200 days of storage at all the storage conditions studied in this work, followed by the drum-dried and freeze-dried samples. A likely explanation for this result is the large difference between the particle size of the spray-dried sample and the other two samples. The difference in particle size means that the spray-dried SMP has a higher surface area compared to the freeze-dried and drum-dried SMPs, which means that the spray-dried SMP has a higher reaction rate than the other samples. Fyfe et al. showed that the average particle size for spray-dried skim milk powder manufactured by Büchi Mini Spray Dryer B-290 was $19.32 \pm 0.91 \mu \mathrm{m}$ and freeze-dried skim milk powder after grinding had $410 \pm 9.41-\mu \mathrm{m}$ particles on average, i.e., 21 times larger particles compared to the spray-dried samples (Fyfe et al. 2011). Similarly, spraydried particle sizes produced by the same mini spray-dryer in another study were reported to be 14-24 $\mu \mathrm{m}$ (Langrish et al. 2006). The feed concentration, inlet temperature, and feed flow rate were the same as in the current study. In order to support the above explanation, we analyzed the samples by scanning electron microscopy (SEM). In Fig. 6 can be seen how the morphology and size of the spray-dried sample are distinctly different from the freeze-dried and drum-dried SMPs which results in its considerably higher surface area and reaction rate.

It should be noticed that storage at $33 \% \mathrm{RH}, 20^{\circ} \mathrm{C}$, did not lead to significant changes in the CML concentrations over the entire storage time $(P>0.05)$, and thus can be considered a favorable storage condition.

Changes of water content during storage of skim milk powders was also monitored (Fig. 7). When stored at 52\% RH, samples absorbed the water so quickly that after only 1 week the water contents reached 7-8\%. This, to some extent, explains their higher reaction rate and their higher CML content compared to $33 \% \mathrm{RH}$. The highest water content the samples could reach at the other studied RH (33\%) was approximately $6 \%$. The point to note here is that the spray-dried samples at all the studied conditions had the lowest water content after 200 days of storage. Changes in water content are related to lactose crystallization phenomena and glass transition (Jouppila et al. 1997; Jouppila and Roos 1994; Roos 2010) which is outside the scope of this study. Water activity $\left(a_{w}\right)$ was the other parameter that was monitored during storage of skim milk powders. The results of these measurements are summarized in Table 2.

The findings of the present study are of crucial value for manufacturers in their effort to control the formation of AGEs in skim milk powders and for consumers in terms of drawing their attention to the importance of high-quality controlled domestic storage. To our knowledge, no previous study has focused on the formation of CML in different types of skim milk powders in terms of prolonged storage effects, bearing in mind that skim milk powders are an essential part of formulation in plenty of food products such as confectionary, infant formulas, and recombined dairy products.

\section{Concluding Remarks}

The focus of this study was to investigate how AGEs, specifically CML, are formed in skim milk powders after opening the packages by the consumers, when they store an open package at room temperature and consume the product intermittently over a long time. Accordingly, various pilot-scale produced skim milk powders were stored under controlled environments for 200 days, and CML formation was monitored using LC-MS/MS.

The findings of this study indicate that the spray-dried samples contained higher CML content after 200 days of storage at all the investigated conditions, followed by the drumdried and freeze-dried samples. Temperature and relative humidity were the investigated storage variables that had significant impact on the formation of CML $(P<0.05)$. Our results elucidate that the effect of relative humidity on CML formation under the conditions of this study was more profound than the impact of temperature, which is useful as RH can be controlled by packaging and appropriate storage conditions. Taken together, the results of this study have significant implications for a large number of food products in which skim milk powder is an essential part of the formulation.

AGE, advanced glycation end product; CML, carboxymethyl lysine; GO, glyoxal; LC-MS/MS, liquid chromatography coupled to tandem mass spectrometry; NFPA, nonafluoropentanoic acid; PUFA, polyunsaturated fatty acids; RH, relative humidity; SEM, scanning electron microscopy; SMP, skim milk powder; SPE, solid phase extraction; SRM, selected reaction monitoring.

Acknowledgements This study was supported by The Swedish Research Council (VR).

Open Access This article is distributed under the terms of the Creative Commons Attribution 4.0 International License (http:// creativecommons.org/licenses/by/4.0/), which permits unrestricted use, distribution, and reproduction in any medium, provided you give appropriate credit to the original author(s) and the source, provide a link to the Creative Commons license, and indicate if changes were made. 


\section{References}

Aalaei, K., Rayner, M., \& Sjöholm, I. (2016a). Storage stability of freezedried, spray-dried and drum-dried skim milk powders evaluated by available lysine. LWT - Food Science and Technology, 73, 675-682. doi:10.1016/j.lwt.2016.07.011.

Aalaei, K., Rayner, M., Tareke, E., \& Sjöholm, I. (2016b). Application of a dye-binding method for the determination of available lysine in skim milk powders. Food Chemistry, 196, 815-820. doi:10.1016/j. foodchem.2015.10.004.

Ahmed, N., Mirshekar-Syahkal, B., Kennish, L., Karachalias, N., BabaeiJadidi, R., \& Thornalley, P. J. (2005). Assay of advanced glycation endproducts in selected beverages and food by liquid chromatography with tandem mass spectrometric detection. Molecular Nutrition \& Food Research, 49(7), 691-699. doi:10.1002/mnfr.200500008.

Bengmark, S. (2007). Advanced glycation and lipoxidation end products - amplifiers of inflammation: the role of food. Journal of Parenteral and Enteral Nutrition, 31(5), 430-440.

Bosch, L., Sanz, M. L., Montilla, A., Alegría, A., Farré, R., \& del Castillo, M. D. (2007). Simultaneous analysis of lysine, NEcarboxymethyllysine and lysinoalanine from proteins. Journal of Chromatography B, 860(1), 69-77. doi:10.1016/j.jchromb.2007. 10.011

Dittrich, R., Hoffmann, I., Stahl, P., Müller, A., Beckmann, M. W., \& Pischetsrieder, M. (2006). Concentrations of $\mathrm{N} \varepsilon$ Carboxymethyllysine in human breast milk, infant formulas, and urine of infants. Journal of Agricultural and Food Chemistry, 54(18), 6924-6928. doi:10.1021/jf060905h.

Drusch, S., Faist, V., \& Erbersdobler, H. F. (1999). Determination of $\mathrm{N} \epsilon-$ carboxymethyllysine in milk products by a modified reversed-phase HPLC method. Food Chemistry, 65(4), 547-553. doi:10.1016/ S0308-8146(98)00244-1.

FAO. (2016). Food outlook: biannual report on global food markets (pp. 48-51). Rome: Food and Agricultural Organisation of the United Nations, Trades and Markets Division.

Fenaille, F., Parisod, V., Visani, P., Populaire, S., Tabet, J.-C., \& Guy, P. A. (2006). Modifications of milk constituents during processing: A preliminary benchmarking study. International Dairy Journal, 16(7), 728-739. doi:10.1016/j.idairyj.2005.08.003.

Fyfe, K., Kravchuk, O., Nguyen, A. V., Deeth, H., \& Bhandari, B. (2011). Influence of dryer type on surface characteristics of milk powders. Drying Technology, 29(7), 758-769. doi:10.1080/07373937.2010. 538481.

Hartkopf, J., Pahlke, C., Lüdemann, G., \& Erbersdobler, H. F. (1994). Determination of $\mathrm{N} \varepsilon$-carboxymethyllysine by a reversed-phase high-performance liquid chromatography method. Journal of Chromatography A, 672(1), 242-246. doi:10.1016/0021-9673(94) 80613-6.

Hull, G. L. J., Woodside, J. V., Ames, J. M., \& Cuskelly, G. J. (2012). Nع(carboxymethyl)lysine content of foods commonly consumed in a Western style diet. Food Chemistry, 131(1), 170-174. doi:10.1016/j. foodchem.2011.08.055.

Jouppila, K., \& Roos, Y. H. (1994). Glass transitions and crystallization in milk powders. Journal of Dairy Science, 77(10), 2907-2915. doi: 10.3168/jds.S0022-0302(94)77231-3.

Jouppila, K., Kansikas, J., \& Roos, Y. H. (1997). Glass transition, water plasticization, and lactose crystallization in skim milk powder. Journal of Dairy Science, 80(12), 3152-3160. doi:10.3168/jds. S0022-0302(97)76286-6.

Kizer, J. R., Benkeser, D., Arnold, A. M., Ix, J. H., Mukamal, K. J., Djousse, L., et al. (2014). Advanced glycation/glycoxidation endproduct carboxymethyl-lysine and incidence of coronary heart disease and stroke in older adults. Atherosclerosis, 235(1), 116-121. doi:10.1016/j.atherosclerosis.2014.04.013.
Langrish, T. A. G., Marquez, N., \& Kota, K. (2006). An investigation and quantitative assessment of particle shape in milk powders from a laboratory-scale spray dryer. Drying Technology, 24(12), 16191630. doi:10.1080/07373930601031133.

Lima, M., Assar, S. H., \& Ames, J. M. (2010). Formation of NE(Carboxymethyl)lysine and loss of lysine in casein glucose-fatty acid model systems. Journal of Agricultural and Food Chemistry, 58(3), 1954-1958. doi:10.1021/jf903562c.

Liu, X., Zheng, L., Zhang, R., Liu, G., Xiao, S., Qiao, X., et al. (2016). Toxicological evaluation of advanced glycation end product $\mathrm{N} \mathcal{E}$ (carboxymethyl)lysine: acute and subacute oral toxicity studies. Regulatory Toxicology and Pharmacology, 77, 65-74. doi:10. 1016/j.yrtph.2016.02.013.

Motarjemi, Y. (1988). A study of some physical properties of water in foodstuffs : water activity, water binding and water diffusivity in minced meat products. Lund: Dept. of Food Engineering, Lund University.

Nass, N., Bartling, B., Navarrete Santos, A., Scheubel, R. J., Börgermann, J., Silber, R. E., et al. (2007). Advanced glycation end products, diabetes and ageing. Zeitschrift für Gerontologie und Geriatrie, 40(5), 349-356. doi:10.1007/s00391-007-0484-9.

Nguyen, H. T., van der Fels-Klerx, H. J., \& van Boekel, M. A. J. S. (2013). N E-(carboxymethyl)lysine: a review on analytical methods, formation, and occurrence in processed food, and health impact. Food Reviews International, 30(1), 36-52. doi:10.1080/87559129. 2013.853774.

Nguyen, J. L., Schwartz, J., \& Dockery, D. W. (2014). The relationship between indoor and outdoor temperature, apparent temperature, relative humidity, and absolute humidity. Indoor Air, 24(1), 103-112. doi:10.1111/ina.12052.

Nguyen, H. T., van der Fels-Klerx, H. J., \& van Boekel, M. A. J. S. (2016). Kinetics of $\mathrm{N} \varepsilon$-(carboxymethyl)lysine formation in aqueous model systems of sugars and casein. Food Chemistry, 192, 125-133. doi:10.1016/j.foodchem.2015.06.110.

Pearce, N. D., Milk Powder (n.d.). New Zealand Institute of Chemistry (NZIC). http://nzic.org.nz/ChemProcesses/dairy/3C.pdf. Accessed 19 Jan 2017

Plaza, M., Östman, E., \& Tareke, E. (2016). Maillard reaction products in powder based food for infants and toddlers. European Journal of Nutrition and Food Safety, 6(2), 65-74.

Poulsen, M. W., Hedegaard, R. V., Andersen, J. M., de Courten, B., Bügel, S., Nielsen, J., et al. (2013). Advanced glycation endproducts in food and their effects on health. Food and Chemical Toxicology, 60, 10-37. doi:10.1016/j.fct.2013.06.052.

Roos, Y. H. (2010). Glass transition temperature and its relevance in food processing. Annual Review of Food Science and Technology, 1, 469-496.

Rückold, S., Grobecker, K. H., \& Isengard, H. D. (2000). Determination of the contents of water and moisture in milk powder. Fresenius' Journal of Analytical Chemistry, 368(5), 522-527. doi:10.1007/ s002160000511.

Schwarzenbolz, U., Hofmann, T., Sparmann, N., \& Henle, T. (2016). Free Maillard reaction products in milk reflect nutritional intake of glycated proteins and can be used to distinguish "organic" and "conventionally" produced milk. Journal of Agricultural and Food Chemistry, 64(24), 5071-5078. doi:10.1021/acs.jafc. $6 \mathrm{~b} 01375$.

Takeuchi, M., Takino, J.-I., Furuno, S., Shirai, H., Kawakami, M., Muramatsu, M., et al. (2015). Assessment of the concentrations of various advanced glycation end-products in beverages and foods that are commonly consumed in Japan. PloS One, 10(3), e0118652. doi:10.1371/journal.pone.0118652.

Tareke, E., Forslund, A., Lindh, C. H., Fahlgren, C., \& Östman, E. (2013). Isotope dilution ESI-LC-MS/MS for quantification of free and total $\mathrm{N} \varepsilon$-(1-Carboxymethyl)-1-lysine and free $\mathrm{N} \varepsilon$-(1-Carboxyethyl)-1-lysine: comparison of total $\mathrm{N} \varepsilon$-(1-Carboxymethyl)-1-lysine levels 
measured with new method to ELISA assay in gruel samples. Food Chemistry, 141(4), 4253-4259. doi:10.1016/j.foodchem.2013.07. 003.

Troise, A. D., Fiore, A., Wiltafsky, M., \& Fogliano, V. (2015). Quantification of $\mathrm{N} \varepsilon$-(2-Furoylmethyl)-1-lysine (furosine), $\mathrm{N} \varepsilon$ (Carboxymethyl)-1-lysine (CML), NE-(Carboxyethyl)-1-lysine (CEL) and total lysine through stable isotope dilution assay and tandem mass spectrometry. Food Chemistry, 188, 357-364. doi: 10.1016/j.foodchem.2015.04.137.

Uribarri, J., Cai, W., Sandu, O., Peppa, M., Goldberg, T., \& Vlassara, H. (2005). Diet-derived advanced glycation end products are major contributors to the body's AGE pool and induce inflammation in healthy subjects. Annals of the New York Academy of Sciences, 1043(1), 461-466. doi:10.1196/annals.1333.052.

Van Nguyen, C. (2006). Toxicity of the AGEs generated from the Maillard reaction: on the relationship of food-AGEs and biological-AGEs. Molecular Nutrition \& Food Research, 50(12), 1140 1149. doi:10.1002/mnfr.200600144.

Vlassara, H., \& Palace, M. R. (2002). Diabetes and advanced glycation endproducts. Journal of Internal Medicine, 251(2), 87-101. doi:10. 1046/j.1365-2796.2002.00932.x. 